\title{
Orientaatioperustan käyttö opetuksessa
}

\section{— Esimerkkinä myyntikoulutus}

\begin{abstract}
Saraneva, Timo, 1983. Orientaatioperustan käyttö opetuksessa, Aikuiskasvatus 3, 4, 162-168. - Artikkelissa kuvataan erään yrityksen myyntikoulutuksen uudistamista kognitiivisen didaktiikan pohjalta. Lähtökohtina on tiedollisen ristiriidan rakentaminen, orientaatioperustan luominen, myyntikeskustelun uudelleenarviointi sekä oppimistapahtuman loppuarviointi.
\end{abstract}

\section{Yleiset lähtökohdat}

\section{Orientaatioperustan merkitys opetuksessa}

Opetuksen lähtökohtana on orientaatioperusta, tiivistetty malli opittavan asian rakenteesta. Se on koko opetuksen kivijalka. Ilman hyvää orientaatioperustaa opetuksesta tulee enemmän tai vähemmän hapuilevaa ja epäjohdonmukaista. Orientaatioperustasta johdetaan motivointijakso, samoin sisältämis- ja ulkoistamisvaiheet sekä kontrolli ja evaluaatio (kuvio 1). Orientaatioperustan rakentaminen on ehkä vaikein asia kognitiivisessa didaktiikassa (Engeström 1982).

Kuvio 1. Orientaatioperustan elementit

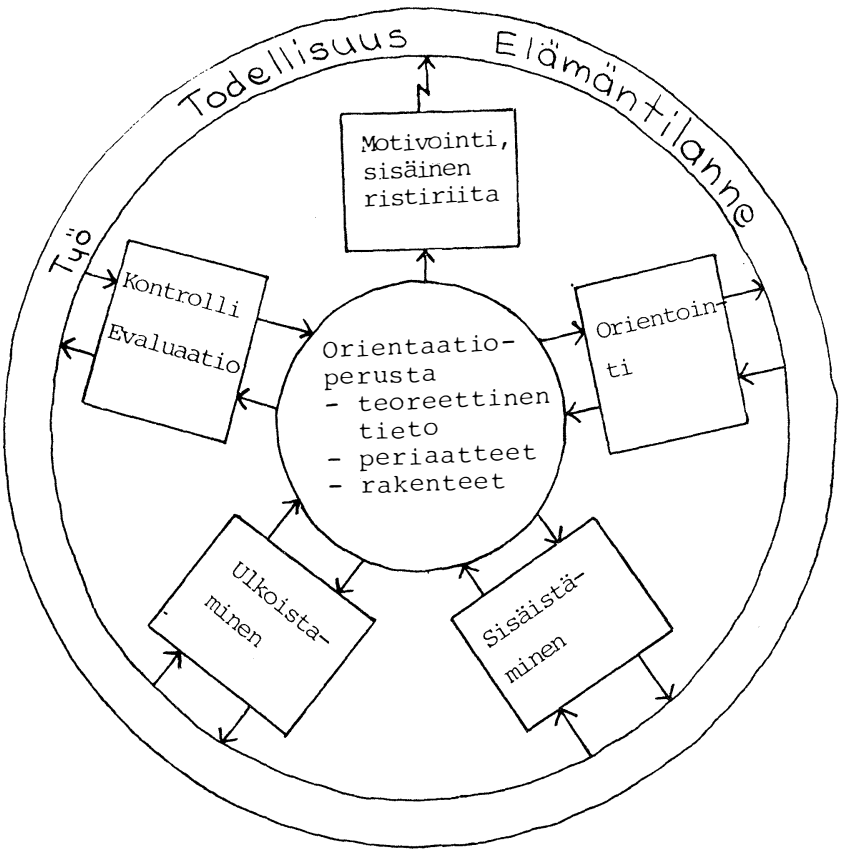

Ilman tietoa ja opetettavan asian syvällistä hallintaa on vaikea rakentaa hyvää orientaatioperustaa. Tässä vaiheessa paljastuvat kouluttajan tiedot tai tietämättömyys opetettavasta asiasta. Siksi on ymmärrettävää, että kouluttaja saattaa sanoa ettei hänellä ole aikaa tehdä orientaatioperustaa. Sen tekeminen vaatii lukemista, tutkimista ja ajattelua.

\section{Koulutustarve}

Huomasimme ServiSystems Oy:ssä, että kilpailijoidemme tarjouskirjeet ovat aivan samannäköisiä kuin oma tarjouskirjeemme. Olimme tilanteessa, jossa asiakas sai käteensä täysin samanlaiset tarjouskirjeet. Asiakas vertasi tarjouksia toisiinsa vain hinnan perusteella. Koska kilpailijamme käyttivät hintaa kilpailukeinona, tarvitsimme uuden tarjousmallin jolla erottautua kilpailijoista. Päätimme muuttaa tarjousmalliamme kilpailukykyisemmäksi seuraavassa myyntiseminaarissa, joita järjestämme vuosittain.

\section{Aikaisempi ajattelumalli}

Aikaisemmin myynnin koulutuksessa oli keskitytty myyntikeskustelun opettamiseen (kuvio 2). Tämä oli johtanut siihen, ettei tar-

Kuvio 2. Myyntikeskustelun malli

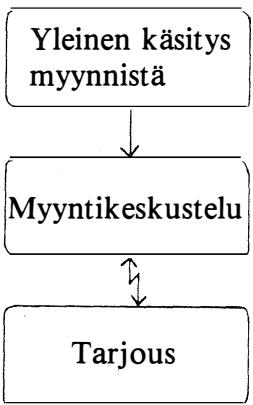


jouksen merkitystä oltu ymmärretty. Vallitsevana käytäntönä oli yhtenäinen ''hallinnollinen' tarjousmalli, jota lähes kaikki yksiköt noudattivat. Koska halusimme muuttaa vallitsevaa tarjouskäytäntöä, meidän oli ensin muutettava yleistä käsitystä myynnistä ts. meidän oli rakennettava uusi syvällisempi myyntityötä koskeva ajattelumalli, myyntityön teoria. Jos olisimme antaneet uuden tarjousmallin valmiina kurssilaisille, olisi vaarana ollut mallin kaavamainen toteutus. Näin vanha kaava olisi vain vaihdettu uuteen kaavaan.

Aikaisemmin oli myyntikoulutuksessa opetettu miten myyntikeskustelu etenee (kuvio 3).

Tästä orientaatioperustasta puuttuu kuitenkin vielä liittymä todellisuuteen. Se ei kerro miksi ja mihin toiminta kohdistuu. Se ei pysty vastaamaan oppilaassa herääviin kysymyksiin ja siksi sen siirtovaikutus on huono. Tuntui tärkeältä kehittää orientaatioperusta, jonka avulla voitaisiin vastata miksi ja mihin -kysymyksiin. Uuden orientaatioperustan lähtökohdaksi otettiin myyntikeskustelun sijasta myyjän ja ostajan välinen vaihtosuhde, jonka pääperiaate on myyjän ja ostajan intressien ero (kuvio 4).

\section{Opetuksen toteutus}

\section{Tiedollisen ristiriidan rakentaminen}

Tiedollisen ristiriidan merkitys koulutustilanteen onnistumisen kannalta on merkittävä. Oppilaille on osoitettava etteivät heidän tietonsa ja taitonsa riitä nykytilanteesta ja tulevaisuudesta selviämiseen. Niinpä heidän on opittava uutta ja kehityttävä selviytyäkseen. Oleellista on, että ristiriita rakennetaan oppilaiden elämäntilanteesta. Oppilaat on saatava tuomaan esiin käsityksensä työnsä ja työssään onnistumisen kannalta oleellisista seikoista (ks. Engeström 1982, s. 28-34).

Tiedollinen ristiriita luotiin myyntiseminaarissa antamalla oppilaille ensin tehtäväksi analysoida yksilötyönä:

— tämän päivän kilpailutilanne

- kilpailun kehitys

- kilpailijoiden kilpailukeinot

Kymmenen minuutin yksilötyön jälkeen oppilaat jaettiin viiteen ryhmään. Ryhmät miettivät yhteisen näkemyksensä näihin kolmeen $\mathrm{ky}$ symykseen.
Kuvio 3. Myyntikeskustelun eteneminen

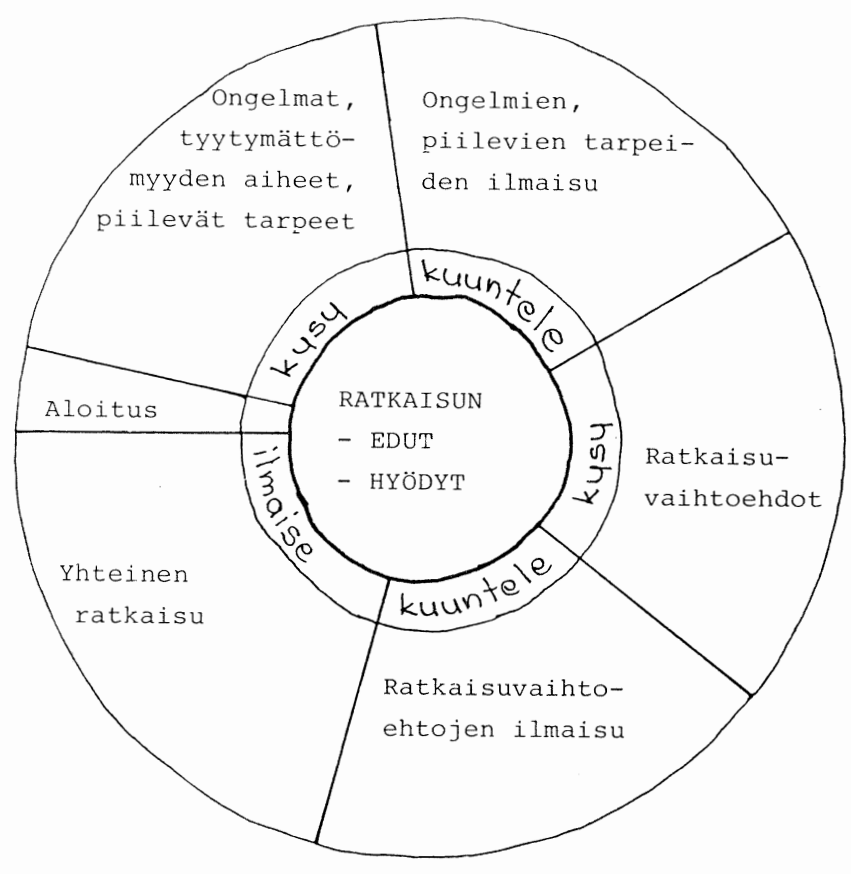

Kuvio 4. Myyntikeskustelun elementit

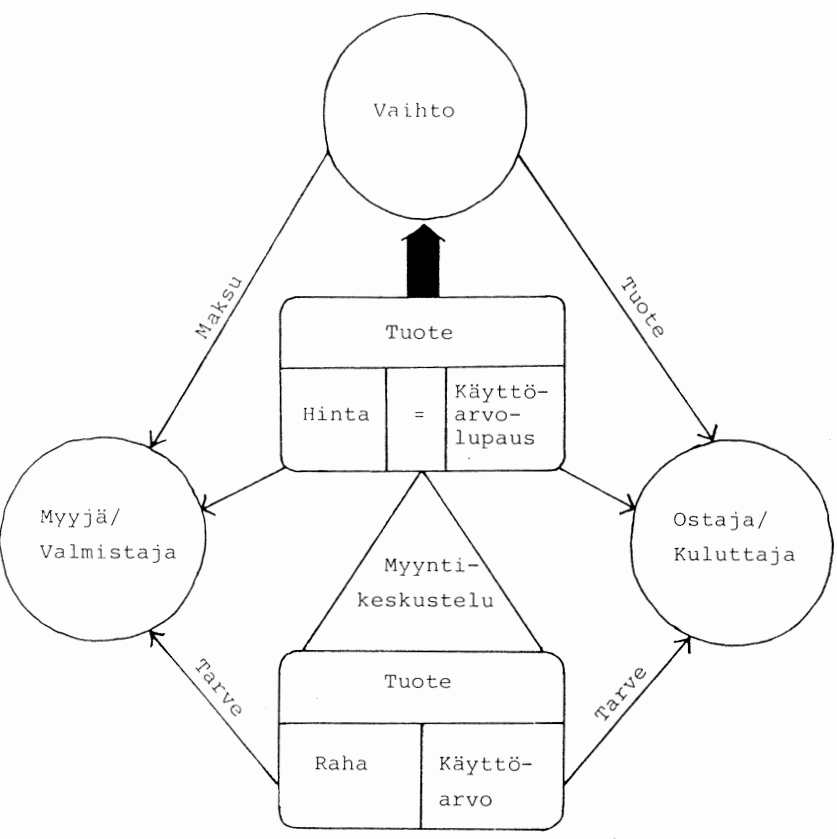


Taulukko 1. Näkemykset kilpailutilanteesta

Ryhmien arviot kilpailutilanteesta $\quad(\mathrm{N}=5)$

1 Kilpailu tänään:

vähäistä

normaalia

kovaa

3

2 Kilpailun kehitys:

vähenee

pysyy ennallaan

kovenee

3 Kilpailukeinot 1 )

hinta

laatu

1)Vastauksien yhteismäärä on suurempi kuin vastaajien määrä, koska kaksi ryhmää on valinnut molemmat vaihtoehdot.

Ryhmätyöstä käydyssä yhteiskeskustelussa päädyttiin siihen, että kilpailu todelia kovenee. Tämän vuoksi on kehitettävä uutta ajattelua ja kehityttävä myynnin osaamisessa. Vertailimme tarjousmalliamme kilpailijoiden tarjouksiin. Keskustelimme, miltä pohjalta asiakas voi tehdä päätöksen verratessaan toisiinsa kahta samanlaista tarjouskirjettä joissa molemmissa on hinte keskellä sivua. Yhteisenä johtopäätöksenä oli, että ratkaiseva peruste millä asiakas voi päättää tai tulee suurella todennäköisyydellä päättämään, on hinta. Kilpailijoiden hinnoittelupolitiikkana on alittaa tarjoushintamme. Näin päädyimme siihen, että tarjousmallimme on saatava eroamaan kilpailijoidemme tarjouskirjeistä.

Tiedollisen ristiriidan luominen onnistui hyvin ja siirryimme opetuksessa orientaatiovaiheeseen.

\section{Orientaatioperusta}

Myyjällä on tarve saada rahaa tuotteesta johon hän on sitonut työtä, pääomaa ja raakaainetta (kuvio 4). Ostaja taas hankkii tuotteen jotain elämäntilannetta varten, jota me voimme kutsua tarpeeksi. Tuotteella on siis ostajalle käyttöarvo. Sen tehtävänä on ratkaista ostajan tai kuluttajan elämäntilanteessa olevia ongelmia. Myyjän intressi on saada rahaa ja ostajan intressi on saada toimiva tuote. Ensimmäinen ristiriita syntyy siitä, ettei ostaja tiedä varmasti tarvitseeko hän todella tätä tuotetta, vai onko kyseessä myyjän hänelle keinotekoisesti synnyttämä tarve.

Toinen ristiriita syntyy myyntikeskustelun edetessä ostajan ja myyjän välillä. Myyjä pyrkii antamaan ostajalle ns. käyttöarvolupauk- sia, vakuuttaakseen ostajan tuotteen toimivuudesta sekä mukanaan tuomista eduista ja hyödyistä. Ostaja pyrkii vertaamaan käyttöarvolupausta myyjän ilmoittamaan hintaan. Kun hinta vastaa ostajan mielestä tuotteen antarnaa käyttöarvolupausta, tapahtuu tuotteen vaihto. Tuote siirtyy ostajalle ja myyjä saa maksun. Tähän on kätkettynä ostajan toinen ristiriita suhteessa myyjään. Käyttöarvolupaus voi toteutua vasta vaihdon tapahduttua. Ostaja pystyy testaamaan sen elävässä elämässä vasta maksettuaan tuotteen hinnan. Ostaja joutuu siis tekemään ostopäätöksen subjektiiviselta pohjalta (F.G. Hauge 1982).

Ostajan kaksi kantavaa ristiriitaa ovat: tarvitseeko hän tuotetta ja mikä tuotteen käyttöarvolupauksen luotettavuus on suhteessa hintaan.

\section{Orientaatioperustan opettaminen}

Orientaatioperustaa opetettaessa käytiin läpi oleelliset asita: mitä tarkoittavat käsitteet "käyttöarvo", "tarve", "myyntikeskustelu", mikä on myyjän intressi, mihin ostaja tarvitsee tuotetta ja mikä käyttöarvolupaus on. Tämän jälkeen anncttiin ryhmille tehtäväksi selvittää mitkä ovat kaksi perustavanlaatuista ristiriitaa ostajan ja myyjän välillä. Tehtävän tarkoituksena oli saada oppilaat sisäistämään orientaatioperusta. He eivät saaneet sitä täysin valmiina vaan joutuivat ristiriitoja etsiessään itse rakentamaan sen mielessään. Kaikki ryhmät löysivät ostajan ja myyjän väliset ristiriidat, kaksi ryhmää tosin hieman haparoiden.

Seuraavaksi ryhmät joutuivat selvittämään, miten nämä kaksi ristiriitaa vaikuttavat myyntityössä. Todettiin myyjän intressin kärjistetysti koskevan vain rahaa, jolloin hän voi herkästi antaa paikkaansapitämättömiä käyttöarvolupauksia ja liioitella tuotteen käyttöarvoa. Näin ollen ostaja on aina ristiriidassa suhteessa myyjään. Tilannetta kuvaavat hyvin sananlaskut "Moni kakku päältä kaunis, vaan on silkkoa sisältä" ja "Ei kaikki ole kultaa mikä kiiltää". Ryhmät päätyivät siihen, että myyjän tärkeä tehtävä on rakentaa perusluottamus ostajan ja itsensä välille.

Orientaatioperustan käyttöä harjoiteltiin ja sovellettiin analysoimalla erään televisiossa käydyn virkistyssaippuakampanjan käyttöarvolupaus ja uskottavuus. Yhteiskeskustelussa käsiteltiin samoin erään pesukonemainoksen käyttöarvolupausta ja uskottavuuttá.

Seuraavaksi ryhmät saivat miettiä johtopäätöksiä yrityksemme myynnin näkökulmasta. Ryhmätöissä tuli selkeästi näkyviin, että palveluyrityksen on menestyäkseen markkinoilla ra- 
kennettava koko palveluprosessinsa siten että tuote todella vastaa asiakkaan tarvetta ja auttaa asiakasta paremmin selviämään omassa toiminnassaan. Toiseksi käyttöarvolupauksen täytyy olla totta. Asiakas valitsee toimittajan, jonka käyttöarvolupaukseen hän luottaa. Hän tekee ostopäätöksensä verrattuaan käyttöarvolupausta ja hintaa keskenään. Yhteiskeskustelussa käytiin vielä läpi ns. korkeapainemyyntiä palvelualalla. Todettiin sen johtavan aina asiakkaan jonkinasteiseen ahdisteluun ja nurkkaan ajamiseen. Näin asiakas saadaan ostamaan tuote kerran, mutta todennäköisesti hän tulee heräämään ja huomaamaan, että häntä on käytetty hyväksi. Tällaista asiakassuhdetta ei voida kutsua luottamukselliseksi.

Lopuksi oppilaille annettiin vielä tehtävä, jolla ei varsinaisesti ollut tekemistä myynnin kanssa. Se oli arviointitehtävä, jotta näkisimme miten oppilaat olivat omaksuneet orientaatioperustan ja miten he pystyivät sitä soveltamaan. Oppilaat saivat selittää kuluttajasuojaorganisaation synnyn annetun orientaatioperustan (kuvio 4) pohjalta. Yleisesti ottaen kaikki löysivät vastauksen annettuun tehtävään. He totesivat kuluttajasuojaorganisaation synnyn olevan johdettavissa siitä, että koska myyjän intressi on saada rahaa, hän saattaa käyttää ostajaa hyväksi antamalla valheellisen käyttöarvolupauksen. Käyttöarvolupaus voi toteutua vasta sen jälkeen kun tuote on ostettu ja ostaja pääsee testaamaan tuotteen vasta maksettuaan sen. Kuluttajasuojaorganisaation tehtävänä on pitää myyjä 'aisoissa"' ja valvoa ettei ostajaa käytetä väärin.

\section{Myyntikeskustelu}

Oleellinen osa myyjän ja ostajan välisestä kommunikaatiosta koskee tuotteen käyttöarvoa, käyttöarvolupausta ja hintaa. Tätä keskustelua kutsutaan myyntikeskusteluksi. Myyntikeskustelun merkitystä lähdettiin selvittämään kuviossa 4 olevan orientaatioperustan pohjalta. Tästä siirryttiin myyntikeskustelun orientaatioperustaan (kuvio 3).

Kuvio 5. Asiakassuhteen rakenne
Myyntikeskustelun toimintatapana on kysy/kuuntele-prosessi (ks. Gordon 1977, s. 58102). Orientaatioperustan ulkokehältä näkyy mihin prosessi eri rooleissa kohdistetaan ja miten siinä jatkuvasti käsitellään ratkaisun etuja ja hyötyjä.

Seuraavaksi kysyttiin, mistä myyntikeskustelun orientaatioperustasta löytyy käyttöarvo ja tarve. Yhteiskeskustelussa todettiin, että myyntikeskustelun orientaatioperustassa ne ovat ongelmat ja piilevät tarpeet. Tämän jälkeen oppilaat etsivät käyttöarvolupauksen.

Käyttöarvolupaus on yhtä hyvin ongelman ratkaisut ja siitä seuraavat edut ja hyödyt. Näin tultiin siihen, että myyntikeskustelussa luodaan luottamuksellisen asiakassuhteen kivijalka. Siinä selvitetään asiakkaan ehdoilla asiakkaan ongelmat ja tarpeet, ei niinkään myyjän tarpeet. Sen jälkeen etsitään ratkaisut ja niistä asiakkaalle seuraavat edut ja hyödyt.

Tämän jälkeen siirryttiin asiakassuhteen rakentamisprosessiin. Tästä oli algoritmityyppinen orientaatioperusta (kuvio 5).

Kuten algoritmista käy ilmi, pitää tarjouksessa näkyä myyntikeskustelussa läpi käydyt asiat. Voidaan sanoa, että tarjous on myyntikeskustelun pelkistetty ja kirjallinen ilmaisu, josta käyvät ilmi asiakkaan ongelmat, tarpeet ja ratkaisut sekä ratkaisuista seuraavat edut ja hyödyt. Lisäksi tarjouksessa näkyy palvelun hinta. Oppilailta kysyttiin miksi tarjouksessa pitää olla edellä olevat asiat. Yhteiskeskustelussa todettiin kuinka tärkeää on, että myyjä on todella kuunnellut asiakasta ja löytänyt asiakkaan todellisen tarpeen. Kun asiakas on itse kuvannut oman elämäntilanteensa, tarpeensa ja odotuksensa pystyy myyjä rakentamaan tuotteen, sen käyttöarvolupauksen ja edut ja hyödyt asiakkaan tarpeita vastaaviksi. Näin yrityksen luotettavuus on aivan toista luokkaa, kuin jos myyjä puhuisi koko ajan osaamatta kuunnella asiakasta. Päädyimme siihen, että tarjous tulee rakentaa räätälintyönä todella asiakkaan elämäntilanteen ja odotusten mukaan eikä niinkuin aikaisemmin, omamme.

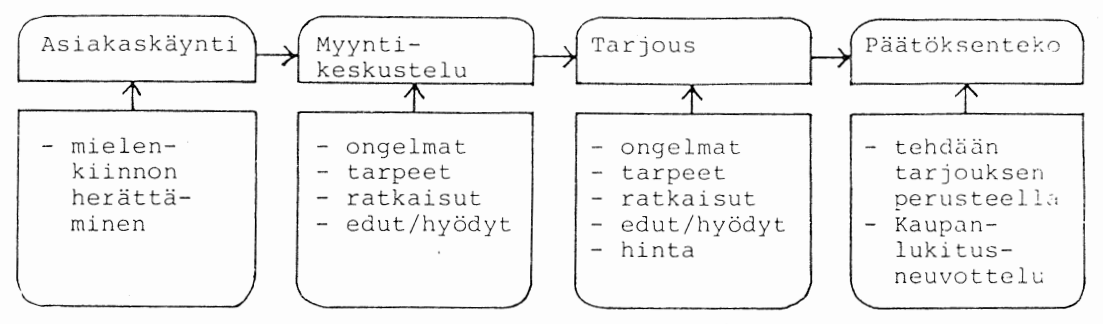


Kun tarjous on jätetty asiakkaalle ja käyty yhdessä asiakkaan yhdyshenkilön kanssa läpi, olemme tavallaan kouluttaneet oman myyntimiehen päätöksentekovaihetta varten. Koska ostopäätökset tehdään pääasiallisesti tarjouksen pohjalta, emmekä pääse mukaan itse päätöksentekovaiheeseen, on tärkeää että meillä on mahdollisimman hyvä kirjallinen myyntimies mukana päätöksenteossa.

Kurssikutsussa olimme pyytäneet jokaista myyntimiestä ottamaan viimeisimmän tarjouksensa mukaan kurssille. Tässä vaiheessa suoritettiin yksilötyönä oman tarjouksen analyysi. Oppilailta kysyttiin:

- miten hinta on esitetty

- löytyvätkö asiakkaan ongelmat tarjouksesta

Tarjouksesta, jossa näkyivät vain työohjeet ja hinta annettiin yksi piste. Edellä kuvatun mallin mukaisesta tarjouksesta voidaan antaa viisi pistettä. Tehtävän tarkoituksena oli edelleenkin syventää tiedollista ristiriitaa. Tehtävää purettaessa huomattiin pistemäärien olevan lähellä yhtä. Suurin osa tarjouksista oli vakiomallin mukaisia.

\section{Harjoitukset}

Uuden orientaatioperustan käyttöä harjoiteltiin seuraavien tehtävien avulla:

\section{Tehtävä}

Toimitusjohtaja x mainitsi, että autonäyttelyn siivoustason pitää olla hyvä. Laatikaa ryhmässä tarjouskirje.

Harjoitustehtävä purettiin ja analysoitiin. Käytiin läpi tarjouksissa olleet puutteet, kehittämisalueet ja mahdolliset vaikeudet joita tämän tyyppisen tarjouksen teossa esiintyy.

\section{Tehtävä}

Myyntikeskustelu, jossa myyntipäällikön tuli kartoittaa asiakkaan ongelmat myyntikeskustelun orientaatioperustan (kuvio 3) avulla. Muiden oppilaiden tehtävänä oli seurata keskustelua ja kirjata siitä oleelliset ongelmat, piilevät tarpeet sekä mahdolliset ratkaisut jotka asiakkaalla oli näkyvissä. Tältä pohjalta he laativat ryhmissä tarjouksen.

\section{Teht $\ddot{a} v \ddot{a}$}

Edellisen mallin mukainen harjoitus, jossa tehtävää vielä vaikeutettiin.

Harjoituksissa edettiin helposta vaikeaan, ryhmätyöstä yksilötehtäviin.

Mikäli myyntikeskustelua ja sen sisältöä ei hallita, on mahdotonta laatia oikeaoppista tarjousta. Ryhmätöitä purettaessa oli selvästi nähtävissä, että ryhmät olivat ymmärtäneet miten uudentyyppinen tarjous rakennetaan. Lisäksi yksi ryhmän jäsenistä joutui käyttämään tehtyä tarjousta myyntikeskustelussa asiakkaan kanssa. Tällä pyrittiin analysoimaan tarjouksen vaikutus asiakkaan näkökulmasta.

\section{Kurssin päättäminen}

Kurssin loppukeskustelussa käytiin läpi uuden tarjousmallin tekoon liittyvät vaikeudet. Vanhan tarjouksen kirjoittamiseen on mennyt viidestä viiteentoista minuuttia. Alkuvaiheessa uuden tarjouksen teko saattaa kestää yhdestä neljään tuntiin. Uusi malli vaatii ajattelua, harjoittelua ja hiomista. Tarjousprosessi ennen tarjouksen laatimista kestää esitutkinta- ja laskentavaiheineen yhdestä kahteen päivään. Ellemme uhraa tarjouksen tekoon aikaa, saattaa tämä kaikki mennä hukkaan. Uuden tarjouksen tekeminen ei ole helppoa, se tulee vaatimaan ponnistelua.

Lopuksi tulosyksiköt, joissa kaikissa on myyntipäällikkö ja ainakin kaksi myyntimiestä, saivat tehdä uuden tarjousmallin käyttöönottosuunnitelman.

\section{Yhteenveto kurssin toteutuksesta}

\section{Orientointi}

Koulutuskokeilussa tuli selvästi esiin kuinka tärkeätä on, että opetuksella on kantava, mahdollisimman suuren siirtovaikutuksen omaava ja miksi -kysymyksiin vastaava orientaatioperusta (kuvio 4), josta voidaan johtaa alemman tason orientaatioperustat (kuviot 3 ja 5). On myös tärkeää, että alemman tason orientaatioperustat niveltyvät koko kurssin orientaatioperustaan. Myyntikeskustelun orientaatioperusta (kuvio 3) on selvästi johdettavissa myyntikeskustelusta (kuvio 4) Algoritmi (kuvio 5) taas kertoo yksityiskohtaisesti myyntiprosessin kehityksen asiakaskäynnistä päätöksentekoon. Algoritmi yksin ei riitä sillä se kertoo vain etenemisjärjestyksen. Molempien alemman tason orientaatioperustojen siirtovaikutus jää rajalliseksi ilman ylemmän tason orientaatioperustaa, koska ne eivät pysty selvittämään ostajan ja myyjän välisiä ristiriitoja. Ne vastaavat $k y-$ symykseen miten, miksi -kysymyksen jäädessä vaille vastausta.

\section{Opetuksellinen kokonaiskäsittely}

Opetuksellista kokonaiskäsittelyä pyrittiin soveltamaan koko kurssin ajan. Motivaation virittämiseksi rakennettiin tiedollinen ristiriita, jota syvennettiin vertaamalla yrityksemme tarjousta kilpailijoiden tarjouksiin sekä saamalla oppilaat analysoimaan oma tarjouksensa. Orientaatiovaiheeseen käytettiin runsaasti aikaa, ennen kaikkea kurssin kantavan orientaatioperustan opettamiseen. Sen omaksuminen on oppimisen kannalta ratkaisevaa ja varmistaa mahdollisimman suuren ja laaja-alaisen 
siirtovaikutuksen. Ylemmän tason orientaatioperustan ymmärtäminen varmistaa alemman tasoisten orientaatioperustojen ymmärtämisen jolloin niitä voidaan käyttää joustavasti ja saumattomasti opetukseen.

Uuden tiedon jakaminen tapahtui pääasiassa algoritmityyppisen orientaatioperustan (kuvio 5) avulla.

Oppilastehtäviä pyrittiin käyttämään mahdollisimman paljon siten, että ne kytkettiin läheisesti oppilaiden omaan elämäntilanteeseen. Myyntikeskusteluharjoitukset kytkettiin todellisuuteen käyttämällä todellisissa tilanteissa esille tulevia asioita.

\section{Evaluaatio}

Oppimisen arvioinnissa pyrittiin etenemään perinteisiä kurssiarviointeja pidemmälle.

\section{Arviointi kurssin aikana}

Oppimista arvioitiin ensimmäisen kerran, kun oppilaille annettiin tehtäväksi selvittää kuluttajasuojaorganisaation synty kurssin kantavan orientaatioperustan (kuvio 4) avulla. Tehtävän tarkoutuksena oli selvittää opettajalle olivatko oppilaat omaksuneet uuden mallin, pystyivätkö he soveltamaan sitä joustavasti. Toisaalta harjoituksen tehtävänä oli auttaa oppilaita kontrolloimaan omaa oppimistaan.

Harjoitustehtävien aikana tapahtui myös koko ajan arviointia:

- nähtiin miten oppiminen etenee

- mitä vaikeuksia siinä on

- minkä tasoisia tarjouksia harjoitustehtävät tuottavat

- minne opetuksen ja soveltamisen painopiste pitää asettaa

- käsiteltiin oppilaiden mieliin tulleita kysymyksiä

\section{Perinteinen kurssiarviointi}

Kurssin lopussa tehtiin myös ns. perinteinen kurssiarviointi. Siinä kysyttiin oppilaiden mielipiteitä tilaisuuteen käyttämästään ajasta. Oppilaat vastasivat seuraavasti:

Taulukko 2. Oppilaiden mielipiteet tilaisuuteen käyttämästään ajasta $(\mathrm{N}=23)$

\begin{tabular}{lrr} 
& \multicolumn{1}{c}{ f } & \multicolumn{1}{c}{$\%$} \\
\hline Todella tuottava investointi & 13 & 56,52 \\
Hyvin käytetty & 8 & 34,78 \\
Hyödyksi & 2 & 8,70 \\
Hyödyksi varauksin & - & 0,00 \\
Hukkaan heitetty & - & 0,00 \\
\hline & 23 & 100,00
\end{tabular}

Tämän arvioinnin mukaan kurssi oli mennyt erittäin hyvin.

Perinteisen kurssiarvioinnin heikkous on, että se kertoo ainoastaan kurssilaisen sen hetkisen tunteen. Koska koulutus tähtää todellisuuden muuttamiseen, pitää arviointi suunnata toiminnan arviointiin (P. Hakkarainen 1982). Tätä tarkoitusta ei perinteinen kurssiarviointi palvele.

\section{Oppimistulosten arviointi käytännön toiminnassa}

Lähetimme myyntiseminaarilaisille kaksi kuukautta kurssin päättymisen jälkeen kyselyn uuden tarjousmallin käyttöönotosta. Kurssilaisia pyydettiin kyselylomakkeen täyttämisen lisäksi liittämään vastaukseen kopiot kahdesta viimeisestä tarjouskirjeestään. Näin voitiin arvioida kurssin vaikutusta myyjien todellisuuteen.

Taulukko 3. Tarjousmallin soveltamisaste $(\mathrm{N}=22)$

\begin{tabular}{llr}
\hline En yhteenkään tarjoukseen & 3 & 13,64 \\
Alle puoleen tarjouksista & 9 & 40,91 \\
Puoleen tarjouksista & 5 & 22,72 \\
Yli puoleen tarjouksista & 4 & 18,18 \\
Jokaiseen tarjoukseen & 1 & 4,55 \\
\hline & 22 & 100,00
\end{tabular}

Oppilaat perustelivat uuden mallin käyttämättä jättämistä mm. seuraavasti:

- Myynti on nyt mennyt niin hyvin, ettei ole tarvetta uuden tarjousmallin käyttöönottoon. Heti kun myynti vaikeutuu, tulen siirtymään uuteen malliin.

- Uusi malli vie liikaa aikaa. Sitä ei kannata käyttää pieniin tarjouksiin, mutta merkittäviin kyllä.

- Kolme vastannutta ei ollut käyttänyt uutta mallia lainkaan. Perusteena oli kokemuksen puute, uutena myyjänä talossa ei vielä ollut aikaa soveltaa sitä.

Kyselyssä tiedusteltiin mm. tarjousten hyväksymisprosenttia. Kuusi oppilasta vastasi tähän kohtaan. Yrityksessämme hyväksymisprosentteja seurataan kuukausittain, joten arviot eivät ole pelkästään subjektiivisia. 
Taulukko 4. Tarjousmallin vaikutus hyväksymisprosenttiin $(\mathrm{N}=6)$

\begin{tabular}{ccc} 
Vastaaja & $\begin{array}{l}\text { Vanha } \\
\text { hyväksymis- } \\
\text { prosentti }\end{array}$ & $\begin{array}{l}\text { Uusi } \\
\text { hyväksymis- } \\
\text { prosentti }\end{array}$ \\
\hline 1 & 35 & 65 \\
2 & 33 & 40 \\
3 & 40 & 45 \\
4 & 70 & 90 \\
5 & 30 & 50 \\
6 & 38 & 90 \\
$\overline{\mathrm{x}}$ & 41 & 63
\end{tabular}

Taulukko 5. Tarjousten laadullinen arviointi $(\mathrm{N}=31)^{1)}$

\begin{tabular}{crr}
$\begin{array}{l}\text { Arviointi- } \\
\text { asteikko }\end{array}$ & $\mathrm{f}$ & $\%$ \\
\hline 1 & 4 & 12,9 \\
2 & 5 & 16,1 \\
3 & 3 & 9,7 \\
4 & 7 & 22,6 \\
5 & 12 & 38,7 \\
\hline & 31 & 100,0
\end{tabular}

1) 18 kurssilaista vastasi tähän kohtaan, näistä 14 lähetti kaksi tarjousta ja kolme yhden, loput neljä eivät lähettäneet yhtään tarjousta.

Laadullinen arviointiasteikko:

Luokka 1 Vanha perinteinen malli, ei muutoksia

Luokka 2 Yksi uusi osatekijä käytössä (ks. kuvio 5)

Luokka 3 Kaksi uutta osatekijää käytössä

Luokka 4 Kolme uutta osatekijää käytössä

Luokka 5 Kaikki osatekijät käytössä

Kysely synnytti uudestaan eräänlaisen tiedollisen ristiriidan. Muutamat, jotka eivät vielä olleet kovin paljon soveltaneet uutta tar- jousmallia, ilmoittivat tehostavansa toimintaansa. Kyselystä tehty yhteenveto postitettiin saatekirjeen ja seitsemän hyvän tarjouksen kanssa myynnille. Palautteen tarjoituksena oli jatkaa tiedollista ristiriitaa siellä missä soveltaminen oli vielä vähäistä ja vahvistaa niitä yksiköitä ja yksilöitä, joilla soveltamisaste oli korkea.

\section{Lopuksi}

Vaikka myyntiseminaari painottui puhtaasti uuden tarjousmallin laadintaan, on tällä tarjousmallia syvällisempi merkitys. Tämän tyyppistä tarjousta ei voi tehdä ilman oikeaoppista myyntikeskustelua (kuvio 3). Ne myyntimiehet, jotka eivät hallitse myyntikeskustelua, eivät pysty tekemään hyvää tarjousta. Näin tarjouksen hallinnasta tulee koko myynnin kehittymisen ja kehittymisvaateen mitta. Jos myyjä (yksikkö) toteaa, ettei hän (se) pysty tämän tyyppistä tarjousta tekemään, on hänen pakko kehittyä.

Uuden tarjouksen ja tarjousmallin teko edellyttää alkuvaiheessa koko myyntiryhmän osallistumista tarjouksen tekoon. Tämä lisää myyntiryhmän kiinteyttä ja auttaa ryhmää oppimaan yhdessä .

\section{Lähteet}

Engeström Yrjö, 1982. Perustietoa opetuksesta, Valtion painatuskeskus, Helsinki

Gordon Thomas, 1977, Viisaat vanhemmat, Tammi, Helsinki

Hakkarainen Pentti, 1982. Arviointi aikuisopetuksessa osa II. Opetuksen ja oppimisen laadullinen evaluointi, Valtion Koulutuskeskus, Julkaisusarja B n:o 20b, Helsinki

Haug W.F., 1982. Mainonta ja kulutus, Gummerus, Jyväskylä 